\title{
HUBUNGAN PENGETAHUAN DAN SIKAP IBU HAMIL TENTANG ANEMIA DENGAN KEJADIAN ANEMIA DI WILAYAH KERJA PUSKESMAS SINGAPARNA KECAMATAN SINGAPARNA KABUPATEN TASIKMALAYA TAHUN 2017
}

\author{
Desi Fauziah \\ Dfauziahnur@,gmail.com
}

\section{A. ABSTRAK}

Survei Demografi Kesehatan Indonesia (SDKI) tahun 2012, Angka Kematian Ibu di Indonesia mencapai 359 per 100.000 kelahiran hidup dan Angka Kematian Bayi mencapai 32 per 1000 kelahiran hidup. Salah satu penyebab utama kematian ibu diantaranya adalah perdarahan. Perdarahan bisa disebabkan oleh anemia. Dari hasil wawancara yang dilakukan penulis terhadap 10 responden didapatkan hasil 8 responden yang mempunyai pengetahuan yang kurang dan sikapnya pun tidak merespon tentang anemia, 2 orang mempunyai pengetahuan cukup tentang anemia. Tujuan penelitian adalah untuk mengetahui hubungan pengetahuan dan sikap ibu hamil tentang anemia dengan kejadian anemia di Wilayah Kerja Puskesmas Singaparna Kecamatan Singaparna Kabupaten Tasikmalaya tahun 2017.

Penelitian ini menggunakan metode penelitian survei (Survey Research Method). Jenis survei yang digunakan dalam penelitian ini adalah jenis survei analitik, dengan pendekatan crossectional. Populasi dalam penelitian ini adalah seluruh ibu hamil trimester 3 di wilayah Kerja Puskesmas Singaparna Kecamatan Singaparna Kabupaten Tasikmalaya yang berjumlah 35 orang, teknik pengambilan sampel menggunakan teknik Total Sampling yaitu sebanyak 35 orang.

Hasil penelitian menunjukkan bahwa pengetahuan ibu hamil tentang anemia ada pada kategori cukup yaitu sebanyak 21 orang (60,0\%). Sikap ibu hamil dalam menghadapi anemia ada pada kategori positif yaitu sebanyak 20 orang (57,1\%). Kejadian anemia pada ibu hamil sebagian besar ada pada kategori anemia yaitu sebanyak 18 orang (51,4\%). Hasil uji statistik dengan menggunakan Chi Square diperoleh nilai p value untuk pengetahuan sebesar 0,001, sedangkan sikap sebesar 0,000. Maka $H_{0}$ ditolak yang artinya bahwa ada hubungan pengetahuan dan sikap ibu hamil tentang anemia dengan kejadian anemia.

Berdasarkan hasil penelitian dapat disimpulkan bahwa kejadian anemia pada ibu hamil dapat disebabkan karena kurangnya pengetahuan dan sikap ibu hamil.

Kata Kunci : : Pengetahuan, sikap, anemia, ibu hamil 


\section{B. PENDAHULUAN}

Angka Kematian Ibu (AKI) dan Angka Kematian Bayi (AKB) merupakan indikator penting dalam menentukan derajat kesehatan masyarakat. Menurut World Health Organization (WHO), padatahun 2014 Angka Kematian Ibu di dunia 210 per 100.000 kelahiran hidup, AKI di negara berkembang 230 per 100.000 kelahiran hidup dan AKI di negara maju 16 per 100.000 kelahiran hidup. AKI di Asia Timur 33 per 100.000 kelahiran hidup, Asia Selatan 190 per 100.000 kelahiran hidup, Asia Tenggara 140 per 100.000 kelahiran hidup dan Asia Barat 74 per 100.000 kelahiran hidup (WHO, 2014).

Survei Demografi Kesehatan Indonesia (SDKI) tahun 2012, Angka Kematian Ibu di Indonesia mencapai 359 per 100.000 kelahiran hidup dan Angka Kematian Bayi mencapai 32 per 1000 kelahiran hidup. Melengkapi hal tersebut, data laporan dari daerah yang diterima Kementerian Kesehatan RI menunjukkan bahwa jumlah ibu yang meninggal karena kehamilan dan persalinan tahun 2013 adalah sebanyak 5019 orang, sedangkan jumlah bayi yang meninggal di Indonesia berdasarkan estimasi SDKI 2012 mencapai 160.681 anak.

Komunikasi Data Kementerian Kesehatan (Komdat Kemenkes) pada tahun 2015, AKI di Jawa Barat sebanyak 227 per 100 ribu kelahiran hidup, dan AKI di Kabupaten Tasikmalaya tahun 2015 sebanyak 55 orang dan jumlah ibu hamil komplikasi sebanyak 7751 per 44214 angka kehamilan dan angka terbanyak kehamilan beresiko terdapat di Puskesmas
Singaparna. Kasus anemia yang terjadi di wilayah Puskesmas Singaparna ini dikarenakan kurangnya pengetahuan ibu hamil mengenai anemia pada kehamilan (Dinkes Kab. Tasikmalaya, 2015).

Salah satu penyebab utama kematian ibu diantaranya adalah perdarahan. Perdarahan bisa disebabkan oleh anemia (WHO, 2014). Anemia adalah keadaan saat jumlah sel darah merah atau jumlah hemoglobin (HB) atau protein pembawa oksigen dalam sel darah merah berada dibawah normal, anemia dalam kehamlian merupakan salah satu masalah kesehatan yang banyak dialami dan cukup tinggi (Saifudin, 2008).

Berdasarkan hasil Riset

Kesehatan Dasar (Riskesdas) tahun 2013, prevalensi anemia pada ibu hamil di Indonesia sebesar 37,1 \%. Pemberian tablet Fe di Indonesia pada tahun 2012 sebesar $85 \%$. Persentase ini mengalami peningkatan dibandingkan pada tahun 2011 yang sebesar 83,3 \%. Meskipun pemerintahsudah melakukan program penanggulangan anemia pada ibu hamil yaitu dengan memberikan 90 tablet $\mathrm{Fe}$ kepada ibu hamil selama periode kehamilan dengan tujuan menurunkan angka anemia ibu hamil, tetapi kejadian anemia masih tinggi (Kemenkes RI, 2013).

Menurut data Riset kesehatan dasar (Riskesdas, 2013), kelompok ibu hamil merupakan salah satu kelompok yang berisiko tinggi mengalami anemia, meskipun anemia yang dialami umumnyamerupakan anemia relatif akibat perubahan fisiologis tubuh selama kehamilan. Anemia pada populasi ibu hamilmenurut kriteria yang ditentukan WHO dan pedoman Kemenkes 1999, yakni sebesar $37,1 \%$ dan prevalensinya hampir sama antara bumil diperkotaan (36,4\%) danperdesaan 40\%. 
Pengetahuan memegang peranan penting di dalam kehidupan seseorang, terutama dalam prilaku hidup sehari-hari, dalam hal ini prilaku kesehatan. Pengetahuan merupakan hasil "tahu" dan ini terjadi setelah orang melakukan pengindraan terhadap suatu objek tertentu. Pengindraan terjadi melalui pancaindra manusia yakni: penglihatan, pendengaran, penciuman, rasa dan raba. Sebagian besar pengetahuan manusia diperoleh melalui mata dan telinga (Notoatmodjo, 2010).

Sikap merupakan reaksi atau respons yang masih tertutup dari seseorang terhadap stimulus atau objek (Azwar, 2011). Seperti pengertian di atas sikap bisa ditunjukkan apabila seseorang mendapat stimulus atau rangsangan. Begitu juga dengan seorang wanita dalam hal sikap terhadap kurangnya mengetahui mengenai anemia. Respon yang diberikan ibu hamil biasanya tertutup terhadap masalah yang dihadapinya.

Dari hasil wawancara yang dilakukan penulis terhadap 10 responden didapatkan hasil 8 responden yang mempunyai pengetahuan yang kurang dan sikapnya pun tidak merespon tentang anemia, 2 orang mempunyai pengetahuan cukup tentang anemia.

Maka dari itu, berdasarkan uraian diatas penulis tertarik untuk melakukan penelitian tentang anemia yang berjudul "Hubungan Pengetahuan dan Sikap Ibu Hamil tentang Anemia dengan Kejadian Anemia di Wilayah Kerja Puskesmas Singaparna tahun 2017'.

\section{METODOLOGI PENELITIAN}

\section{Desain Penelitian}

Jenis survei yang digunakan dalam penelitian ini adalah jenis survei analitik. Pendekatan (jenis) yang digunakan yaitu rancangan survey cross sectional.

\section{Waktu dan Lokasi Penelitian}

Penelitian ini dilakukan di wilayahkerja Puskesmas Singaparna Kecamatan Singaparna Kabupaten Tasikmalaya pada bulan Maret-April 2017.

\section{Subjek Penelitian}

Populasi dalam penelitian ini adalah seluruh ibu hamil trimester 3 di wilayah Kerja Puskesmas Singaparna Kecamatan Singaparna Kabupaten Tasikmalaya yang berjumlah 35 orang.

Teknik pengambilan sampel menggunakan teknik Total Sampling.

\section{Variabel Penelitian}

Variabel independen dari penelitian ini adalah pengetahuan dan sikap tentang anemia dan variabel dependen adalah kejadian anemia.

\section{Instrumen Penelitian}

Instrumen penelitian yang digunakan adalah lembar kuesioner, formulir observasi, dan $\mathrm{Hb}$ digital merk quickcheck.

\section{Analisa Data}

Analisis data yang digunakan dalam penelitian ini terdiri dari analisis univariat dan bivariat Rumus perhitungan untuk analisis univariat menggunakan rumus persentase, dengan rumus sebagai berikut: 
$\mathrm{P} \square \mathrm{X} \times 100 \%$

$\mathrm{N}$

Keterangan:

$\mathrm{P}:$ persentase

$\mathrm{X}$ : jumlahresponden berdasarkan kategori

b. : jumlah seluruh responden Sedangkan untuk uji bivariatmenggunakan uji $C h i$ Square.

\section{HASIL PENELITIAN}

1. Hasil Penelitian

a. Analisis Univariat

1) Pengetahuan ibu tentang anemia

Tabel 1

Distribusi Frekuensi Pengetahuan Ibu Hamil Tentang Anemia Di Wilayah Kerja Puskesmas Singaparna Kabupaten Tasikmalaya Tahun 2017

\begin{tabular}{|c|c|c|}
\hline Pengetahuan & F & \% \\
\hline Kurang & 2 & 5,7 \\
\hline Cukup & 21 & 60,0 \\
\hline Baik & 12 & 34,3 \\
\hline Jumlah & 35 & 100 \\
\hline
\end{tabular}

Berdasarkan Tabel $\quad 1$ menunjukkan bahwa pengetahuan ibu hamil tentang anemia di Wilayah Kerja Puskesmas Singaparna Kabupaten Tasikmalaya tahun 2017 sebagian besar ada pada kategori cukup yaitu sebanyak 21 orang $(60,0 \%)$
2) Sikap ibu dalam menghadapi anemia

Tabel 2

Distribusi Frekuensi Sikap Ibu Hamil dalam Menghadapi Anemia Di Wilayah Kerja Puskesmas Singaparna Kabupaten Tasikmalaya Tahun 2017

\begin{tabular}{|c|c|c|}
\hline Sikap & F & \% \\
\hline Negatif & 15 & 42,9 \\
\hline Positif & 20 & 57,1 \\
\hline Jumlah & 35 & 100 \\
\hline
\end{tabular}

Berdasarkan Tabel 2 menunjukkan bahwa sikap ibu hamil dalam menghadapi anemia di Wilayah Kerja Puskesmas Singaparna Kabupaten Tasikmalaya tahun2017 sebagian besar ada pada kategori positif yaitu sebanyak 20 orang $(57,1 \%)$. 
3) Kejadian anemia pada ibu hamil Tabel 3

Distribusi Frekuensi Kejadian Anemia pada Ibu Hamil

Di Wilayah Kerja Puskesmas Singaparna Kabupaten Tasikmalaya Tahun 2017

\begin{tabular}{|c|c|c|}
\hline Anemia & F & \% \\
\hline Tidak anemia & 17 & 48,6 \\
\hline Anemia & 18 & 51,4 \\
\hline Jumlah & 35 & 100 \\
\hline
\end{tabular}

Berdasarkan Tabel 3 menunjukkan bahwa kejadian anemia pada ibu hamil di Wilayah Kerja Puskesmas Singaparna Kabupaten Tasikmalaya tahun 2017 sebagian besar ada pada kategori anemia yaitu sebanyak 18 orang $(51,4 \%)$.

\section{b. Analisis Bivariat}

1) Hubungan Pengetahuan dengan Kejadian Anemia

Tabel 4

Tabulasi Silang Hubungan

Pengetahuan dengan Kejadian

Anemia pada Ibu Hamil di Wilayah

Kerja Puskesmas Singaparna

Kabupaten Tasikmalaya Tahun 2017

Kejadian

Anemia

Tidak

$\underline{\text { Pengetahuan anemia Anemia Total }}$

\begin{tabular}{|c|c|c|c|c|c|c|}
\hline & $\mathrm{f}$ & $\%$ & $\mathrm{f}$ & $\%$ & $\mathrm{f}$ & $\%$ \\
\hline Kurar & 0 & 0 & 2 & 100 & 2 & 100 \\
\hline Cukup & 6 & 28,6 & 15 & 71,4 & 21 & 100 \\
\hline Baik & 11 & 91,7 & 1 & 8,3 & 12 & 100 \\
\hline Jumlah & 17 & 48,6 & 18 & 51,4 & 35 & 100 \\
\hline$P$ value & & & & 001 & & \\
\hline
\end{tabular}

Berdasarkan Tabel 4 menunjukkan bahwa ibu hamil dengan pengetahuan cukup sebanyak 15 orang $(71,4 \%)$ mengalami kejadian anemia. Dibandingkan dengan ibu dengan pengetahuan baiksebanyak 2 orang $(100,0 \%)$ tidak mengalami anemia. Hasil uji statistik dengan menggunakan Chi Square diperoleh nilai $p$ value sebesar 0,001, jika dibandingkan dengan nilai $\square$ $(0,05)$ makanilai $\mathrm{p}$ lebih kecil daripada nilai $\square(0,001<0,05)$, maka $\mathrm{H} 0$ ditolak yang artinya bahwaada hubunganpengetahuan dengankejadian anemia pada ibu hamil di WilayahKerja Puskesmas Singaparna KabupatenTasikmalaya tahun 2017.

2) Hubungan Sikap dengan Kejadian Anemia

Tabel 5

Tabulasi Silang Hubungan Sikap denganKejadian Anemia pada Ibu Hamil di Wilayah Kerja puskesmas Singaparna Kabupaten Tasikmalaya Tahun 2017

\begin{tabular}{|c|c|c|c|c|c|}
\hline \multirow[b]{2}{*}{ Sikap } & \multicolumn{5}{|c|}{$\begin{array}{l}\text { Kejadian } \\
\text { Anemia }\end{array}$} \\
\hline & & & Ane & & Total \\
\hline & $f$ & $\%$ & $f$ & $\%$ & $\mathrm{f} \%$ \\
\hline & 1 & 6,7 & 14 & 93,3 & $15 \quad 100$ \\
\hline & 16 & 80,0 & 4 & 20,0 & $20 \quad 100$ \\
\hline Jumlah & 17 & 48,6 & 18 & 51,4 & $35 \quad 100$ \\
\hline Pvalue & & & & 01 & \\
\hline
\end{tabular}

Berdasarkan Tabel 5 menunjukkan bahwa ibu hamil dengan sikap negatif sebanyak 14 orang (93,3\%) mengalami kejadian anemia. Dibandingkan dengan ibu dengan sikap positif sebanyak 16 orang $(80,0 \%)$ tidak mengalami anemia. Hasil uji statistik dengan menggunakan Chi Square diperoleh nilai $p$ value sebesar 0,000 , jika dibandingkan dengan nilai $\square(0,05)$ 
maka nilai p lebih kecil daripada nilai $\square(0,000$ $<0,05)$, maka H0 ditolak yang artinya bahwa ada hubungan sikap dengan kejadian anemia pada ibu hamil di Wilayah Kerja Puskesmas Singaparna Kabupaten Tasikmalaya tahun 2017.

\section{E. PEMBAHASAN}

\section{Hubungan Pengetahuan dengan Kejadian Anemia}

Berdasarkan hasil penelitian menunjukkan bahwa hasil uji statistik dengan menggunakan Chi Square diperoleh nilai $p$ value sebesar 0,001 ,jika dibandingkan dengan nilai $\square(0,05)$ maka nilai p lebih kecil daripada nilai $\square(0,001$ $<0,05)$, maka H0 ditolak yang artinya bahwa ada hubungan pengetahuan dengan kejadian anemia pada ibu hamil di Wilayah Kerja Puskesmas Singaparna Kabupaten Tasikmalaya tahun 2017.

Adanya hubungan ini disebabkan karena pengetahuan secara langsungdapat mempengaruhi terhadap kejadian anemia, semakin baik pengetahuan ibu tentang asupan nutrisi selama kehamilan maka resiko terhindar dari kejadian anemia semakin kecil, begitu juga sebaliknya jika pengetahuan ibu tentang asupan nutrisi kurang baik, kemungkinan ibu mengalami anemia semakin besar.

Hasil penelitian ini sejalan dengan penelitian yang dilakukan oleh Purbadewi (2013) yang menyatakan bahwa ada hubungan tingkat pengetahuan tentang anemia dengan kejadian anemia pada ibu hamil di

Puskesmas Moyudan Sleman Yogyakarta. Tingkat pengetahuan tentang anemia pada ibu hamil di Puskesmas Moyudan masih banyak yang termasuk kategori kurang. Ibu hamil yang mempunyai tingkat pengetahuan kurang tentang anemia berarti pemahaman tentang pengertian anemia, hal-hal yang menyebabkan anemia, tanda dan gejala anemia, hal-hal yang diakibatkan apabila terjadi anemia, maupun tentang perilaku kesehatan untuk mencegah terjadinya anemia menjadi kurang untuk dapat menghindari terjadinya anemia kehamilan. Pengetahuan merupakan hasil "tahu" dan ini terjadi setelah orang melakukan penginderaan terhadap suatu obyek tertentu. Penginderaan terjadi melalui panca indera manusia,yakni: indera penglihatan, pendengaran, penciuman, rasa dan raba. Sebagian besar pengetahuan manusia diperoleh melalui mata dan telinga (Notoatmodjo, 2010).

Faktor yang mempengeruhi pengetahuan adalah pendidikan, informasi, budaya, pengalaman (Notoatmodjo, 2010). Dalam penelitian ini mempunyai kelemahan diantaranya tidak ada faktor yang mempengaruhi pengetahuan.

Berdasarkan uraian tersebut, peneliti berpendapat bahwa adanya hubungan antara pengetahuan ibu hamil dengan kejadian anemiadisebabkan karena kurangnya pengetahuan yang diperoleh ibu hamil mengenai nutrisi makanan, sehingga akan berdampak terhadap kejadian anemia.

\section{Hubungan Sikap dengan Kejadian Anemia}

Hasil penelitian menunjukkan bahwa hasil uji statistik dengan menggunakan Chi Square diperoleh nilai $p$ value sebesar 0,000 , jika dibandingkan dengan nilai $\square(0,05)$ maka nilai $\mathrm{p}$ lebih kecil daripada nilai $\square(0,000<0,05)$, maka H0 ditolak yang artinya bahwa ada hubungan sikap dengan kejadian anemia pada ibu 
hamil di Wilayah Kerja Puskesmas Singaparna Kabupaten Tasikmalaya tahun 2017.

Adanya hubungan antara sikap dengan kejadian anemia pada ibu hamil disebabkan karena sikap ibu hamil dalam menjaga kehamilannya masih kurang, salah satunya contohnya adalah ibu jarangg memeriksakan kehamilannya kepada petugas kesehatan, selain itu juga sikap ibu hamil dalam mengonsumsi makanan yang bergizi masih kurang baik.

Penelitian yang dilakukan oleh Rofiani (2016) menyatakan bahwa dari 51 responden yang memiliki sikap kurang baik sebesar 50 responden $(98,0 \%)$ mengalami anemia sedangkan 1 responden $(2,0 \%)$ yang memiliki sikap kurang baik tidak mengalami anemia. Dari hasil analisis diperoleh $\mathrm{OR}=154.545$ artinya ibu hamil yang memiliki sikap kurang baik mempunyai risiko 154 kali lebih tinggi mengalami anemia dibandingkan dengan ibu yang memiliki sikap baik. Menurut penjelasan di atas peneliti dapat menyimpulkan bahwa konsumsi tablet $\mathrm{Fe}$ harus diimbangi dengan sikap yang baik seperti pada penelitian yang dilakukan menunjukkan bahwa ada hubungan antara sikap ibu dalam mengkonsumsi tablet Fe dengan kejadian anemia dan sebagian besar ibu memiliki sikap yang kurang baik.

Tetapi dalam penelitian ini responden yang memiliki sikap positif sebanyak 4 responden mengalamikejadian anemia. Hal ini disebabkan karena sikap merupakan sebagian kecil faktor yang mempengaruhi tidak terjadinya anemia, adapun faktor-faktor yang mempengaruhi anemia adalah karakteristik Individu (umur, suku bangsa, agama, pendidikan, paritas) dan konsumsi zat gizi (kecukupan Konsumsi Kalori, kecukupan konsumsi protein, kecukupan konsumsi tablet $\mathrm{Fe}$ ).
Sikap merupakan determinan perilaku, karena mereka berkaitan dengan persepsi, kepribadian dan motivasi. Sebuah sikap merupakan suatu keadaan siap mental, yang dipelajari dan diorganisasi menurut pengalaman dan yang menyebabkan timbulnya pengaruh khusus atau reaksi seseorang terhadap orang-orang, objek-objek dan situasisituasi dengan siapa dia berhubungan. Menurut Lapierre dan Allport, sikap merupakan semacam kesiapan untuk bereaksi terhadap suatu obyek dengan cara-cara tertentu. Dapat dikatakan bahwakesiapan yang dimaksudkan merupakan kecenderungan potensial untuk bereaksi dengan cara tertentu apabila individu dihadapkan pada suatu stimulus yang menghendaki adanya respon (Munandar, 2011).

Dari hasil penelitian ini dinyatakan sikap positif jika sebagian besar responden tidak mengalami anemia, dikatakan sikap positif jika penilaian dari kuesioner lebih dari 50\%. Jika sikap negatif maka responden sebagian besar mengalami anemia,dikatakan sikap negatif jika penilaian kuesioner kurang dari 50\%. Peneliti berharap dengan memiliki sikap yang positif, tidak ada responden yang mengalami kejadian anemia. Faktor yang mempengaruhi sikap diantaranya pengalaman pribadi, pengaruh orang lain yang dianggap penting, pengaruh kebudayaan, media massa, lembaga pendidikan dan lembaga agama, emosional kelemahan dalam penelitian ini tidak ada faktor yang mempengaruhi sikap di kendalikan.

Dengan demikian dapat disimpulkan bahwa sikap selain dipengaruhi oleh pengalaman pribadi seseorang juga dipengaruhi oleh situasi lingkungan yang didasari oleh emosi. Demikian pula dengan sikap ibu dalam menghadapi anemia erat kaitannya dengan pengaruh lingkungan sekitarnya. 


\section{F. KESIMPULAN DAN SARAN}

\section{Kesimpulan}

a. Kejadian anemia pada ibu hamil diWilayahKerjaPuskesmasSingaparna Kabupaten Tasikmalaya sebagian besar terjadi anemia dengan persentase $51,4 \%$

b. Pengetahuan ibu hamil tentang anemia di Wilayah Kerja Puskesmas Singaparna Kabupaten Tasikmalaya ada pada kategori cukup.

c. Sikap ibu hamil dalam menghadapi anemia di Wilayah Kerja Puskesmas Singaparna KabupatenTasikmalaya ada pada kategoripositif.

d. Ada hubungan antara pengetahuan dengan kejadian anemia pada ibu hamil di Wilayah Kerja Puskesmas Singaparna Kabupaten Tasikmalaya

d. Ada hubungan antara sikap dengan kejadian anemia pada ibu hamil di Wilayah Kerja Puskesmas Singaparna Kabupaten Tasikmalaya

\section{Saran}

Diharapkan dengan koseling yangdiberikan tentanganemia, ibu hamil dapat mengetahui apabilaterdapatfaktor risiko yang dapat diatasi sedini mungkin. Dan meningkatkan pengetahuan dan sikapnya dalammenghadapi kejadian anemia dengan selalu melakukan pemeriksaankehamilan secara rutin.

\section{H. DAFTAR PUSTAKA}

Arikunto, S. 2006: Prosedur Penelitian Suatu Pendekatan Praktis. Jakarta: Rineka Cipta

Arisman, 2007: Gizi Dalam Daur Kehidupan. Jakarta : Penerbit Buku Kedokteran.

Azwar, S. 2011. Sikap Manusia Teori dan Pengukurannya. Yogyakarta: Pustaka Pelajar.

Departemen Kesehatan RI. 2010. Profil Kesehatan Indonesia http://www.depkes.go.id

Dinas Kesehatan Kabupaten Tasikmalaya, 2015: Data AKI, AKB, Kehamilan Resiko. Tasikmalaya

Jurnal http://id.portalgaruda.org/ diakses pada tanggal 26 Agustus2016

Jurnal. http://ejournal.kopertis10.or.id diakses pada tanggal 02 September 2016

Kementerian Kesehatan RI. 2010. Riset Kesehatan Dasar 2010. Jakarta

Kemenkes. RI. (2013). Buku Saku Pelayanan Kesehatan Ibu di Fasilitas Kesehatan Dasar dan Rujukan. Edisi ke-1 : Jakarta

Kemenkes (2005) AKI di Jawa Barat. tersedia dalam http://www.komdat.kemkes.go.id/ diakses tanggal 26 Agustus 2016

Kemenkes RI. 2013 Riset Kesehatan Dasar. RISKESDAS. Jakarta: Balitbang Kemenkes RI

Manuaba, IBG. 2010. Ilmu Kebidanan untuk Pendidikan Bidan Edisi 2. Jakarta: EGC

Mansjoer 2008. Kapita Selekta Kedokteran. Jakarta : Media Aesculap

Notoatmodjo, S. 2007: Ilmu Kesehatan Masyarakat. Rineka Cipta: Jakarta

Notoatmodjo, S. 2010. Metodologi Penelitian Kesehatan. Rineka Cipta: Jakarta 
Notoatmodjo, S. 2012: Promosi Kesehatan dan Perilaku Kesehatan. Rineka Cipta: Jakarta

Pudiastuti, Ratna Dewi. 2012. Asuhan Kebidanan Pada Hamil Normal \& Patologi. Yogyakarta: Nuha Medika

Saifuddin, A. B, 2009. Pelayanan Kesehatan Maternal dan Neonatal, Jakarta: Yayasan Bina Pustaka Sarwono Prawirohardjo

Sarwono Prawirohardjo SDKI (2012) AKI dan AKB, tersedia dalam http://www.depkes.go.id/ diakses tanggal 26 Agustus 2016

Sugiyono, 2013. Metode Penelitian Kombinasi. Bandung: Alfabeta
Varney, S, 2007. Buku Saku Bidan, Jakarta Penerbit Buku Kedokteran, EGC

Varney, S, 2009. Buku Ajar Asuhan Kebidanan, Jakarta. Penerbit Buku Kedokteran, EGC

WHO (2014) Angka Kematian Ibu dan Angka Kematian Bayi. Tersedia dalam: http:who.go.id

Winkjosastro, H. 2010. Ilmu Kebidanan. Jakarta: Yayasan Bina pustaka Sarwono Prawiroharjo 